\title{
HUBUNGAN ANTARA PARADIGMA LINGKUNGAN BARU DENGAN PERILAKU TANGGUNG JAWAB LINGKUNGAN SISWA
}

\author{
Septika Augis Ulmi Kaan ${ }^{1}$, I Made Putrawan ${ }^{2}$, Mieke Miarsyah ${ }^{3}$ \\ 1 Stur \\ Student of Biology Education Departement of State University of Jakarta \\ ${ }^{2}$ Environmental Education Departement of State University of Jakarta \\ ${ }^{3}$ Biology Education Departement of State University of Jakarta \\ Email : septikaaugisulmikaan@gmail.com,putrawan.imade@yahoo.com, \\ mmiarsyah@unj.ac.id
}

\begin{abstract}
This study aims to determine the relation between the new environmental paradigm to responsible environmental behavior in high school students in Jakarta. The research was conducted at Jakarta State Senior High School 53 in the first semester of the 2017/2018 Academic Year. The method used is a survey method with correlational techniques. The sample used was 89 students of class XI MIA random sampling. Data was collected using new environmental paradigm instruments and responsible environmental behavior instruments. Data analysis was done by simple linear regression test to measure the magnitude of the relation using the Pearson Product Moment formula at the 5\% significance level. The results of the study show that there is a positive and significant the relation between the new environmental paradigm to responsible environmental behavior. The correlation coefficient of this study is 0.276 . The contribution of the new environmental paradigm variable to responsible environmental behavior variable is $7.6 \%$. Therefore, the environmental paradigm has a role in improving student's responsible environmental behavior.
\end{abstract}

Keywords: new environmental paradigm, responsible environmental behavior, students.

\begin{abstract}
ABSTRAK
Penelitian ini bertujuan untuk mengetahui hubungan antara paradigma lingkungan baru dengan perilaku tanggung jawab lingkungan pada siswa SMA di Jakarta. Penelitian dilaksanakan di SMA Negeri 53 Jakarta pada Semester I Tahun Ajaran 2017/2018. Metode yang digunakan adalah metode survei dengan teknik korelasional. Sampel yang digunakan berjumlah 89 siswa kelas XI MIA yang dipilih secara acak. Data dikumpulkan menggunakan instrumen paradigma lingkungan baru dan instrumen perilaku tanggung jawab lingkungan. Analisis data dilakukan dengan uji regresi linear sederhana untuk mengukur besarnya hubungan digunakan rumus Pearson Product Moment pada taraf signifikansi 5\%. Hasil penelitian menunjukkan terdapat hubungan positif dan signifikan antara paradigma lingkungan baru dengan perilaku tanggung jawab lingkungan. Besar koefisien korelasi penelitian ini adalah 0,276. Kontribusi variabel paradigma lingkungan baru terhadap variabel perilaku tanggung jawab lingkungan siswa sebesar $7,6 \%$. Oleh karna itu, paradigma lingkungan memiliki peranan dalam memperbaiki perilaku tanggung jawab lingkungan siswa.
\end{abstract}

Kata kunci : paradigma lingkungan baru, perilaku tanggung jawab lingkungan, 


\section{PENDAHULUAN}

Menurut Hernandez, perilaku tanggung jawab lingkungan adalah kaitan antara variabel status ekonomi, masyarakat pedesaan atau pendatang (urban), tingkat informasi atau pengetahuan tentang lingkungan, peran dari adanya intensif, self esteem, locus of control, self efficacy, keyakinan dan sikap pada lingkungan. Secara khusus perilaku tanggung jawab lingkungan muncul karena adanya nilai, norma, sikap dan keyakinan. Nilai teridentifikasi dan muncul dalam gaya hidup seseorang sebagai perwujudan dari keyakinan pada sesuatu. Nilai, norma, sikap, dan keyakinan berkaitan dengan keberpihakan pada lingkungan membangun lahirnya perilaku tanggung jawab lingkungan. (Jorge \& Lucila, 2010)

Menurut Cook. S. dan Berrenberg, perilaku tanggung jawab lingkungan adalah suatu keharusan untuk mencakup berbagai perilaku yang dapat diamati berupa "tujuan" berkontribusi untuk solusi dari masalah lingkungan di sekitar kita. (Stuart \& Joy, 1981) Perilaku manusia pada hakikatnya adalah suatu tindakan atau aktivitas dari manusia itu sendiri. Pengalaman tidak berdiri sendiri dalam pembentukan perilaku tapi dapat bergabung dengan faktor-faktor lain seperti pengetahuan, persepsi, sikap, keinginan,dan lain-lain.

Dunlap dan Van Liere memandang perilaku tanggung jawab lingkungan sebagai ekspresi atau dimensi kepedulian lingkungan yang terdiri dari kegiatan yang mengusulkan bagaimana individu memecahkan masalah lingkungan. (Dunlap \& VanLiere, 1984) Menurut Chiras D. Daniel Perilaku tanggung jawab lingkungan memiliki ciri sebagai berikut: (a) berpandangan bahwa sumber daya alam terbatas untuk manusia dan (b) manusia adalah bagian dari alam berpandangan bahwa alam ada tidak untuk dikuasai dan digunakan dalam memenuhi kebutuhan hidup manusia secara berlebihan. (Chiras, 1991).

Model yang menggambarkan keterkaitan antara variabel pengetahuan dan variabelvariabel lainnya dalam pembentukan perilaku tanggung jawab lingkungan digambarkan melalui model perilaku Hines sebagai berikut: 


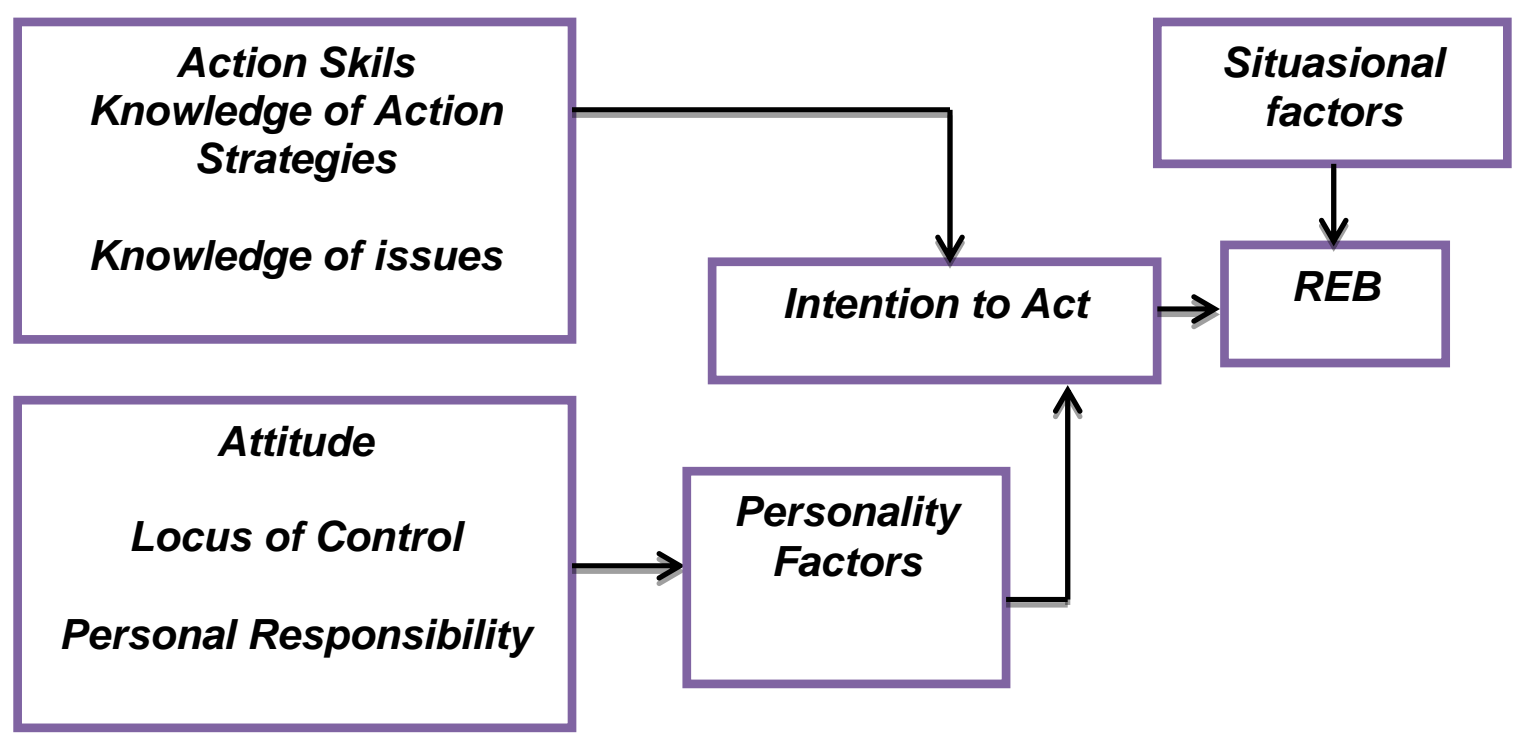

Gambar 1. Model Hines yang Menggambarkan Pembentukan Responsible Environmental Behavior (2010)

Model tersebut menggambarkan bahwa untuk terbentuknya perilaku tanggung jawab lingkungan dipengaruhi oleh variabel pengetahuan. Pengetahuan tentang strategi dan tindakan yang akan digunakan seseorang terhadap lingkungannya dan juga pengetahuan terhadap isu yang ada di lingkungan. Faktor-faktor lain selain pengetahuan yang juga mempengaruhi perilaku tanggung jawab lingkungan adalah: kepribadian, sikap terhadap lingkungan (attitudes), dan pengambilan tindakan (locus of control) dan faktor situasional. Faktor situasional adalah kondisi sesaat pada tempat dan waktu tertentu. Salah satu faktor situasional adalah paradigma lingkungan baru.

Berdasarkan uraian konsep dan teori, maka perilaku tanggung jawab lingkungan adalah tindakan siswa pada kehidupan sehari-hari terutama dalam interaksinya dengan lingkungan serta dalam rangka pelestarian lingkungan dan aktivitas lingkungan untuk mengatasi masalah-masalah yang berkaitan dengan lingkungan.

Menurut Thomas Kuhn paradigma lingkungan baru adalah suatu cara pandang, nilainilai, metode-metode, prinsip dasar dan dapat memecahkan suatu masalah yang dianut oleh suatu masyarakat ilmiah pada saat tertentu di lingkungan. Paradigma merupakan pandangan yang mendasar bagi para ilmuan mengenai apa yang menjadi pokok permasalahan yang seharusnya dipelajari oleh satu cabang ilmu pengetahuan tertentu. (Thomas, 2002) Paradigma membantu memberikan definisi tentang apa yang harus dipelajari, pertanyaan apa yang harus dikemukakan, bagaimana pertanyaan itu dikemukakan, dan peraturan apa yang harus dipatuhi 
dalam menginterpretasi jawaban yang diperoleh. Paradigma mengajarkan untuk mencintai lingkungan dan mampu hidup dengan lingkungan yang sehat.

Paradigma lingkungan baru adalah untuk membedakan orang-orang pada pandangan dunia yang berbeda berdasarkan pada keyakinan tentang hak dan tanggung jawab manusia dalam kaitannya dengan sisa alam, dan menghindari referensi untuk masalah lingkungan tertentu. (Hodis \& Luis, 2014)

Awalnya, pandangan dunia mengarah pada paradigma anti-environmental. Individu melihat dunia dengan asumsi bahwa manusia dipisahkan dari alam, dan manusia lebih berharga dari pada organisme lain. Manusia memiliki kekuasaan dalam penggunaan sumber daya alam.

Di bawah paradigma ini, dunia memiliki upaya konservasi hanya pada sumber daya alam yang terbatas. Upaya konservasi dilakukan pada bagian-bagian lingkungan yang memiliki nilai komersil bagi manusia. Paradigma ini dinamakan Dominance Social Paradigm (DSP) atau Dominasi Paradigma Sosial yang ditandai dengan manusia berpandangan bahwa ekosistem atau lingkungan memiliki kemungkinan mengalami kehancuran. (Pratima \& Andrew, 2012) Selain itu, untuk sumber daya alam yang tidak terbatas, dapat dimanfaatkan secara tidak rasional untuk pemenuhan kebutuhan dasar manusia. Dominance Social Paradigm (DSP) memandang manusia memiliki kekuatan atas alam sehingga timbul pandangan Anthropocentris. Dominance Social Paradigm adalah salah satu paradigma yang memengaruhi perilaku manusia sebelum memasuki abad ke-2. Seiring berkembangnya zaman, paradigma ini dinilai tidak efektif untuk keberlangsungan sumber daya alam. (Anderson et. al., 2012)

Terbentuk paradigma baru yaitu New Environmental Paradigm (NEP) yang menganggap bahwa manusia adalah bagian dari ekosistem dan sumber daya alam yang sangat terbatas untuk dimanfaatkan dan cenderung menjadi langka. Adanya pengetahuan tentang lingkungan manusia diajarkan untung peduli dan bertanggung jawab terhadap lingkungan agar tidak memakai sumber daya alam secara berlebihan. Paradigma ini merupakan campuran dari nilai-nilai antara DSP dan eco-sentrisme yang berfokus pada pentingnya lingkungan alam untuk kesehatan dan kesejahteraan manusia. Paradigma ini mengenali keseimbangan alam dan mampu menghadapi masalah lingkungan akibat campur tangan manusia yang berlebihan. ( J. Thomson, 2013)

Menrut Dunlap, et al, paradigma lingkungan baru (new environmental paradigm) terdiri atas 5 dimensi yaitu : 1) Realitas tentang adanya batas pertumbuhan (Limits to growth), 2) Anti-antroposentrisme (Anti-antropocentricsm), 3) Kerapuhan pada 
keseimbangan alam (The fragility of natures balance), 4) Penolakan terhadap exemtionalism (Rejection of examptionalism), 5) Kemungkinan adanya krisis ekologi (the possibility of an ecocrisis). (Dunlap, et. al., 2002)

Berdasarkan uraian dan teori, maka paradigmaa lingkungan baru siswa adalah cara pandang baru siswa tentang lingkungan yang dikonstruksikan dalam pikiran, kemudian dijadikan pedoman mendasar siswa ketika berinteraksi dengan lingkungannya dan tindakan dalam mengelola lingkungan.

Rumusan masalah pada penelitian ini adalah: apakah terdapat hubungan antara paradigma lingkungan baru dengan perilaku tanggung jawab lingkungan pada siswa SMA di Jakarta?. Penelitian ini bertujuan untuk mengetahui hubungan antara paradigma lingkungan baru dengan perilaku tanggung jawab lingkungan pada siswa SMA di Jakarta.

\section{METODOLOGI PENELITIAN}

Metode yang digunakan dalam penelitian ini adalah metode deskriptif dengan studi korelasional. Dalam penelitian ini terdapat dua variabel yang diteliti yaitu paradigma lingkungan baru yang merupakan variabel bebas (X) dan perilaku tanggung jawab lingkungan siswa yang merupakan variabel terikatnya $(Y)$. Desain penelitian yang digunakan dalam penelitian ini dapat digambarkan sebagai berikut:

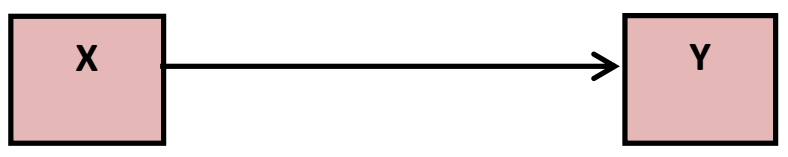

Gambar 2. Desain Penelitian Hubungan antara X dan Y

Dalam penelitian ini populasinya adalah seluruh siswa SMA kelas XI IPA di Provinsi DKI Jakarta. Penentuan sampel dalam penelitian ini menggunakan teknik pemilihan sampel bertingkat (multi stage sampling) dengan tahapan sebagai berikut: pertama, dengan menggunakan teknik purposive sampling dari seluruhan SMA di DKI Jakarta dan dipilih SMAN di Jakarta Timur. Kedua, dengan menggunakan teknik cluster random sampling dari seluruh kecamatan di wilayah Jakarta Timur terpilih kecamatan Jatinegara. Ketiga, dengan menggunakan teknik cluster random sampling dari seluruh SMAN di kecamatan di Jatinegara terpilih SMAN 53 Jakarta Timur sebagai tempat penelitian. Keempat, dengan menggunakan teknik cluster random sampling terpilih siswa kelas XI dari kelas X, XI dan 
XII. Kelima, dengan menggunakan teknik purposive sampling dipilih kelas XI IPA. Keenam, dengan menggunakan teknik cluster random sampling terpilih 92 siswa sebagai responden dari seluruh kelas XI IPA. Ketujuh, dengan menggunakan teknik Simple Random Sampling diambil secara acak 89 sampel dari 92 responden yang terpilih. Teknik pengumpulan data yang digunakan adalah metode survei. Digunakan dua macam instrumen berupa opinioner yaitu instrumen paradigma lingkungan baru dan instrumen perilaku tanggung jawab lingkungan siswa.

\section{HASIL DAN PEMBAHASAN}

Hasil pengujian regresi linier sederhana menunjukkan data paradigma lingkungan baru dan perilaku taggung jawab lingkungan siswa membentuk model regresi yang signifikan dan linier dirumuskan sebagai berikut $\hat{Y}=43,896+0,309 X$. Persamaan tersebut menunjukkan bahwa hubungan antara paradigma lingkungan baru dengan perilaku tanggung jawab siswa bernilai positif, berarti apabila paradigma lingkungan baru (X) bertambah 1 skor, maka akan diikuti oleh kenaikan skor perilaku tanggu jawab lingkungan siswa (Y) sebesar 0,309 dengan konstanta 43,896. Dapat dilihat dalam tabel 1. berikut ini :

\begin{tabular}{|c|c|c|c|c|c|c|c|c|}
\hline \multirow[t]{2}{*}{ Model } & \multicolumn{2}{|c|}{$\begin{array}{l}\text { Unstandardized } \\
\text { Coefficients }\end{array}$} & \multirow{2}{*}{$\begin{array}{c}\begin{array}{c}\text { Standardized } \\
\text { Coefficients }\end{array} \\
\text { Beta }\end{array}$} & \multirow[t]{2}{*}{$\mathrm{T}$} & \multirow[t]{2}{*}{ Sig. } & \multicolumn{3}{|c|}{ Correlations } \\
\hline & B & $\begin{array}{l}\text { Std. } \\
\text { Error }\end{array}$ & & & & $\begin{array}{l}\text { Zero- } \\
\text { order }\end{array}$ & Partial & Part \\
\hline (Constant) & 43,896 & 14,940 & & 2,938 & ,004 & & & \\
\hline NEP & ,309 &, 115 & ,276 & 2,675 & ,009 & ,276 & ,276 & 276 \\
\hline Dependent Varial & EB & & & & & & & \\
\hline
\end{tabular}

Sebelum model regresi tersebut dianalisis lebih lanjut, terlebih dahulu dilakukan uji signifikan dan linieritas model persamaan regresi.

\section{a. Uji Keberartian Persamaan Regresi}

Uji keberartian regresi menggunakan uji ANAVA regresi dari variabel yang diukur. Hasil uji regresi signifikansi disajikan dalam tabel 2. berikut ini: 
Tabel 2. ANAVA Uji Signifikan Persamaan Regresi Linear Sederhana

\begin{tabular}{|c|c|c|c|c|c|c|}
\hline \multirow{2}{*}{ Model } & & $\begin{array}{c}\text { Sum } \\
\text { Of Squares }\end{array}$ & Df & Mean Square & $\mathrm{F}$ & Sig. \\
\hline & Regression & 964,970 & 1 & 964,970 & 7,158 &, $009^{\mathrm{b}}$ \\
\hline \multirow{2}{*}{1} & Residual & 11728,559 & 87 & 134,811 & & \\
\hline & Total & 12693,528 & 88 & & & \\
\hline \multicolumn{7}{|c|}{ a. Dependent Variable: REB } \\
\hline
\end{tabular}

Hasil pengujian keberartian model regresi pada $a=0,05$ menunjukkan $F_{\text {hitung }}$ lebih besar dari pada $\mathrm{F}_{\text {tabel }}$ yaitu 7,158 > 3,96 maka tolak $\mathrm{H}_{0}$. Hal ini menunjukkan model regresi sederhana $\hat{Y}=43,896+0,309 X$ adalah signifikan.

\section{b. Uji Linearitas Persamaan Regresi}

Uji linearitas menggunakan uji ANAVA regresi dari setiap variabel yang diukur.

Hasil uji linearitas regresi disajikan dalam tabel 3. berikut ini:

Tabel 3. ANAVA Uji Linearitas Persamaan Regresi Linear Sederhana

\begin{tabular}{|c|c|c|c|c|c|c|c|}
\hline & & & $\begin{array}{c}\text { Sum } \\
\text { Of Squares }\end{array}$ & Df & $\begin{array}{l}\text { Mean } \\
\text { Square }\end{array}$ & $\mathrm{F}$ & Sig. \\
\hline \multirow{5}{*}{$\mathrm{Y} * \mathrm{X}$} & \multirow{3}{*}{$\begin{array}{l}\text { Between } \\
\text { Groups }\end{array}$} & (Combined) & 4322,397 & 32 & 135,075 & ,904 & ,615 \\
\hline & & Linearity & 964,970 & 1 & 964,970 & 6,455 & ,014 \\
\hline & & $\begin{array}{l}\text { Deviation from } \\
\text { Linearity }\end{array}$ & 3357,428 & 31 & 108,304 &, 725 & ,833 \\
\hline & Within Groups & & 8371,131 & 56 & 149,484 & & \\
\hline & Total & & 12693,528 & 88 & & & \\
\hline
\end{tabular}

Hasil pengujian linieritas pada model regresi $\hat{Y}=43,896+0,309 X$ dengan $\alpha=0,05$ diperoleh $\mathrm{F}_{\text {hitung }}$ lebih kecil dari pada $\mathrm{F}_{\text {tabel }}$ yaitu $0,725<1,74$ maka terima $\mathrm{H}_{0}$, sehingga bentuk hubungan antara paradigma lingkungan baru dengan perilaku tanggung jawab lingkungan siswa adalah linier. Secara visual dapat dilihat pada gambar 5 berikut : 


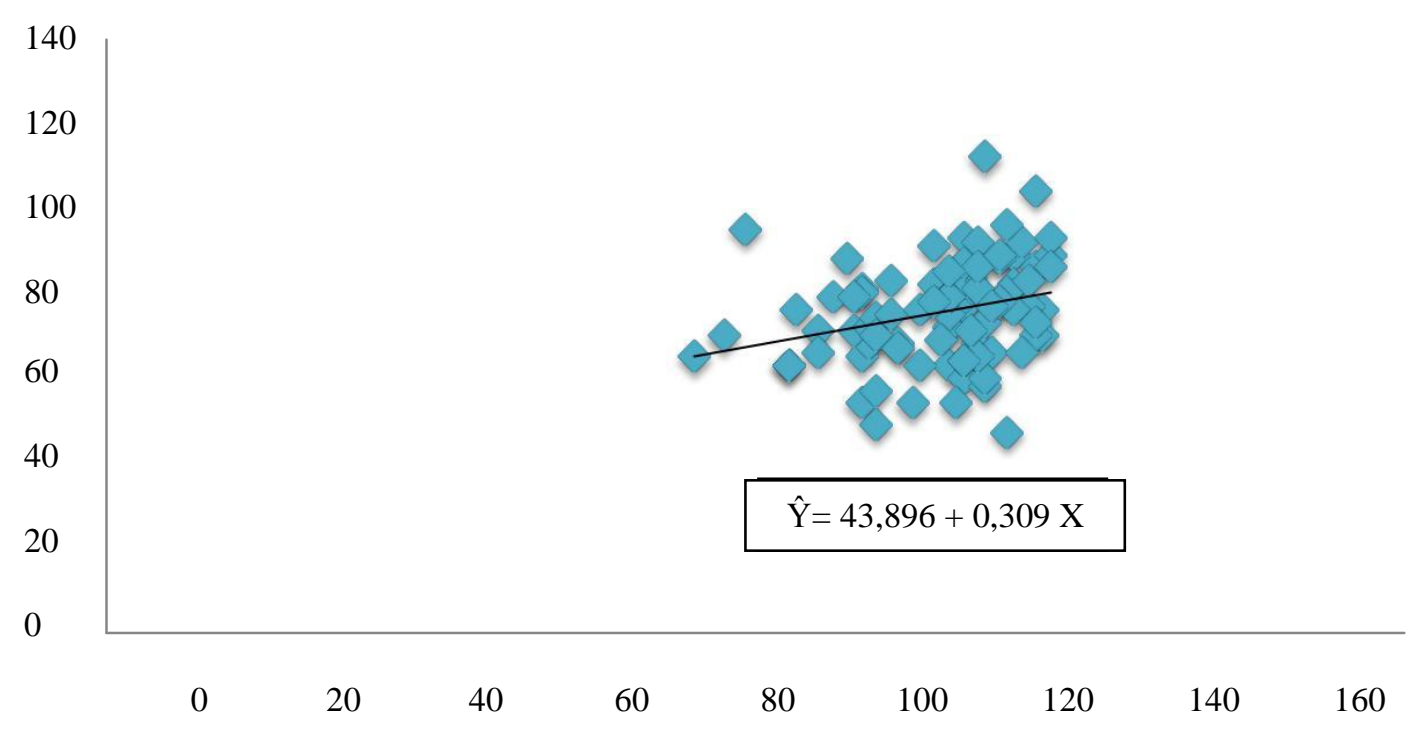

\section{Gambar 7. Model Regresi Linear antara Paradigma Lingkungan Baru dengan Perilaku Tanggung Jawab Lingkungan Siswa}

\section{c. Menghitung Koefisien Korelasi}

Koefisien korelasi dihitung dengan rumus Pearson Product Momen. Berdasarkan hasil perhitungan dan pengujian, diperoleh besarnya koefisien korelasi dapat dilihat pada tabel 4. berikut :

Tabel 4. Koefisien Korelasi antara Paradigma Lingkung Baru (X) dengan Perilaku Tanggung Jawab Lingkungann (Y).

\begin{tabular}{|llll|}
\hline & & NEP & REB \\
\cline { 2 - 4 } & Pearson Correlation & 1 &, $276^{* *}$ \\
\hline \multirow{3}{*}{ NEP } & Sig. (2-tailed) & &, 009 \\
\cline { 2 - 4 } & $\mathrm{N}$ & 89 & 89 \\
\cline { 2 - 4 } & Pearson Correlation &, $276^{* *}$ & 1 \\
\hline \multirow{2}{*}{ REB } & Sig. (2-tailed) &, 009 & 89 \\
\cline { 2 - 4 } & $\mathrm{N}$ & 89 & \multirow{2}{*}{89} \\
\hline
\end{tabular}

**. Correlation is significant at the 0.01 level (2-tailed).

Hasil pengujian koefisien korelasi antara paradigma lingkungan baru dengan perilaku tanggung jawab lingkungan menunjukkan $\rho_{x y}>0$ yaitu 0,276 $>0$ maka terdapat hubungan yang positif. 


\section{d. Uji signifikansi koefisien korelasi}

Berdasarkan hasil perhitungan uji signifikansi koefisien korelasi dengan $a=0,05$ didapatkan thitung lebih besar dari pada $t_{\text {tabel }}$ yaitu 2,675 >1,664. Hal ini menunjukkan bahwa koefisien korelasi signifikan, dapat dilihat pada tabel 5. berikut:

Tabel 5. Uji Signifikansi Koefisien Korelasi

\begin{tabular}{|c|c|c|c|c|c|c|c|c|}
\hline \multirow[t]{3}{*}{ Model } & \multirow{2}{*}{\multicolumn{2}{|c|}{$\begin{array}{c}\text { Unstandardized } \\
\text { Coefficients }\end{array}$}} & \multirow{3}{*}{$\begin{array}{c}\text { Standardized } \\
\text { Coefficients }\end{array}$} & \multirow[t]{3}{*}{$\mathrm{T}$} & \multirow[t]{3}{*}{ Sig. } & \multicolumn{2}{|c|}{ Correlations } & \multirow[t]{3}{*}{ Part } \\
\hline & & & & & & \multirow{2}{*}{$\begin{array}{l}\text { Zero- } \\
\text { order }\end{array}$} & \multirow[t]{2}{*}{ Partial } & \\
\hline & B & $\begin{array}{l}\text { Std. } \\
\text { Error }\end{array}$ & & & & & & \\
\hline (Constant) & 43,89 & 14,940 & & 2,938 & ,004 & & & \\
\hline 1 & 6 & & & & & & & \\
\hline NEP & ,309 &, 115 & ,276 & 2,675 & ,009 & ,276 & ,276 & ,276 \\
\hline
\end{tabular}

Berdasarkan hasil pengujian koefisien korelasi dan uji signifikansi koefisien korelasi maka, koefisien korelasi tersebut signifikan dan terdapat hubungan positif antara paradigma lingkungan baru dengan perilaku tanggung jawab lingkungan siswa.

\section{e. Menghitung Koefisien Determinasi}

Perhitungan koefisien determinasi dilakukan untuk mengetahui besarnya konstribusi variabel $\mathrm{X}$ terhadap variabel $\mathrm{Y}$. Berdasarkan hasl perhitungan diperoleh nilai koefisien determinasi sebesar 0,076. Nilai koefisien determinasi dapat dilihat pada tabel 6 . berikut:

Tabel 6. Pengujian Koefisien Determinasi antara Paradigma Lingkung Baru (X) dengan Perilaku Tanggung Jawab Lingkungann (Y)

\begin{tabular}{|c|c|c|c|c|c|c|c|c|c|}
\hline \multirow[b]{2}{*}{ Model } & \multirow[b]{2}{*}{$\mathrm{R}$} & \multirow[b]{2}{*}{$\begin{array}{c}\mathrm{R} \\
\text { Square }\end{array}$} & \multirow[b]{2}{*}{$\begin{array}{l}\text { Adjusted R } \\
\text { Square }\end{array}$} & \multirow{2}{*}{$\begin{array}{c}\text { Std. } \\
\text { Error of } \\
\text { the } \\
\text { Estimate }\end{array}$} & \multicolumn{5}{|c|}{ Change Statistics } \\
\hline & & & & & $\begin{array}{c}\text { R } \\
\text { Square } \\
\text { Change }\end{array}$ & $\begin{array}{c}\mathrm{F} \\
\text { Change }\end{array}$ & Df 1 & Df 2 & $\begin{array}{l}\text { Sig. F } \\
\text { Change }\end{array}$ \\
\hline 1 &, $276^{\mathrm{a}}$ & ,076 & 065 & 11,61081 & ,076 & 7,158 & 1 & 87 & ,009 \\
\hline \multicolumn{10}{|c|}{ a. Predictors: (Constant), NEP } \\
\hline & $\overline{\mathrm{de}}$ & lable: & & & & & & & \\
\hline
\end{tabular}

Hal tersebut dapat diinterpretasikan bahwa variabel paradigma lingkungan baru memberikan konstribusi terhadap variabel perilaku tanggung jawab lingkungan siswa sebesar $7,6 \%$, sedangkan $92,4 \%$ ditentukan oleh faktor lain.

Berdasarkan hasil pengujian hipotesis diketahui terdapat hubungan positif antara paradigma lingkungan baru dengan perilaku tanggung jawab lingkungan siswa. Hal ini terbukti pada hasil persamaan regresi yang menunjukkan adanya hubungan linier antara 
paradigma lingkungan baru dengan perilaku tanggung jawab lingkungan. Artinya, semakin baik paradigma lingkungan baru yang dimikili oleh siswa maka semakin baik pula perilaku tanggung jawab lingkungan yang dimiliki siswa. Individu yang memperoleh skor paradigma lingkungan baru yang tinggi akan lebih memberikan dukungan terhadap berbagai kegiatan lingkungan dibandingkan individu yang memiliki skor paradigma lingkungan baru yang rendah. (Dunlap, et. al., 2002)

Nilai koefisien korelasi $\left(\mathrm{r}_{\mathrm{xy}}\right)$ sebesar 0,276 yang artinya kedua variabel memiliki nilai korelasi yang rendah. Nilai koefisien determinasi kedua variabel sebesar 0,076 dapat diinterpretasikan bahwa paradigma lingkungan baru memiliki kontribusi sebesar 7,6\% terhadap perilaku tanggung jawab lingkungan. Paradigma lingkungan baru berhubungan dengan perilaku tanggung jawab siswa, namun paradigma lingkungan baru bukan satusatunya faktor yang membentuk perilaku tanggung jawab lingkungan siswa. Terdapat 92,4\% ditentukan oleh faktor situasional lain yang tidak diamati dalam penelitian ini.

Sesuai dengan pernyataan Hines, bahwa terbentuknya perilaku tanggung jawab lingkungan dipengaruhi oleh beberapa faktor, diantaranya adalah sikap, locus of control, kemampuan bertindak, pengetahuan tentang strategi untuk tindakan, pengetahuan tentang isu lingkungan, faktor kepribadian, dan faktor situasional yang meliputi paradigma lingkungan baru, environmental sensitivity, faktor ekonomi atau faktor jenis kelamin. (Hines, Hungerford, Tomera, 1987) Faktor situasional yang lain menjadi penyebab rendahnya kontribusi paradigma lingkungan baru terhadap perilaku tanggung jawab lingkungan siswa.

Dani Vardiansyah dalam bukunya yang menyatakan bahwa "paradigma merupakan cara pandang orang terhadap diri dan lingkungannya yang akan mempengaruhi pola berpikir (kognitif), bersikap (afektif), dan bertingkah laku (konatif).” (Dunlap, et. al., 2002) Tingkah laku inilah yang tercermin pada aktivitas tanggung jawab lingkungan. Niat untuk bertindak diasumsikan sebagai pandangan individu yang akan memengaruhi perilaku tanggung jawab lingkungan. Contoh dalam kehidupan sehari-hari adalah pemakaian sumber daya secara hemat, tidak melakukan perusakan serta memelihara kebersihan dan keindahan lingkungan sehingga terpeliharanya keasrian lingkungan.

Pada Tahun 2017, R. R. Nurul Wardhani melakukan penelitian yang berjudul pengaruh Personality dan New Environmental Paradigm terhadap Responsible Environmental Behaviour siswa. Hasil dari penelitian ini adalah perilaku tanggung jawab lingkungan siswa secara langsung dipengaruhi oleh paradigma lingkungan baru yang dimiliki siswa dan personality siswa tidak terbukti berpengaruh secara langsung terhadap perilaku tanggung jawab lingkungan siswa. (Raden, 2017) 
Pada tahun 2017, I Made Putrawan melakukan penelitian dengan judul Predicting Students Responsible Environmental Behavior (REB) Based on Personality Stidents New Environmental Paradigm (NEP) and Naturalistic Intelligence, hasil penelitiannnya menyatakan bahwa responsible environmental behavior dapat dipengaruhi oleh faktor-faktor seperti new environmental paradigm dan personality. Dari penelitian tersebut menunjukan bahwa perilaku tanggung jawab seseorang terhadap lingkungan dapat dipengaruhi oleh cara pandang positif seseorang terhadap lingkungannya. Ketika cara pandang seseorang terhadap lingkungannya baik, maka akan mempengaruhi perilakunya terhadap lingkungan. (Putrawan, 2017)

Siswa dengan cara pandang yang baik memiliki kepedulian yang tinggi dan kesadaran bahwa dirinya menjadi bagian yang tidak terpisahkan dari lingkungan. Memandang lingkungan sebagai bagian yang tidak bisa dipisahkan dari manusia menyebabkan siswa lebih menghargai keberadaan alam, lebih mencintai kebersihan lingkungan, dan tidak mengeksploitasi pemakaian sumber daya alam. Maka dari itu untuk memenuhi segala kebutuhan hidup, siswa hasrus menyadari akan pentingnya memiliki perilaku tanggung jawab terhadap lingkungan yang baik.

\section{KESIMPULAN}

Temuan dalam penelitian ini adalah adanya hubungan positif antara paradigma lingkungan baru dengan perilaku tanggung jawab lingkungan pada siswa. Hal tersebut menunjukkan bahwa semakin tinggi skor paradigma lingkungan baru maka semakin baik perilaku tanggung jawab siswa.

\section{DAFTAR PUSTAKA}

Bansal, P. and Hoffman, A. J. (2012). The Oxford Handbook of Business and the Natural Environment. Oxford: OUP Oxford.

Bechtel, R. B. and Churchman, A. (2001). Handbook of Envirronmental Psychology. New York: John Wiley \& Sons. Inc.

Chiras, D. D. (1991). Enviromental Science: Action for a Sustainable Future. California: The Benjamin/Cummings Pub. Co. Inc.

Cook, S. W. and Berrenberg, J. L. (1981). Approaches to Encouraging Conservation Behavior: A Review and Conceptual Framework. Journal of Social Issues. 37(2), 73107.

Dunlap, R. E. and Van Liere K. D. (1984). Commitment to the dominantsocial paradigm and concern for environmental quality. Oklahoma State University: Social Sci. Q. 
Dunlap, R. E, et. al. (2000). New Trens in Measuring Environmental Attitudes: Measuring Endorsement of the New Ecological Paradigm: A revised NEP Scale. Journal of Social Issues. 56 (3), 430.

Hines, J. M., Hungerford, H. M., Tomera, A. M. (2010). Analysis and Synthesis of Research on Responsible Environmrntal Behavior : A meta-Analysis. Juornal of Environmental Education 18(2), 7.

Kuhn, T. S. (2002). The Structure of Scientific Revolutions. Bandung: PT Remaja Rosdakarya.

Lorin, W. A., Krathwohl, D. R., Bloom, B. S. (2012). A Taxonomy for Learning, Teaching and Assessing: A Revision of Bloom's Taxonomy of Educational Objectives. New York: Longman.

Putrawan, I Made. (2017) "Predicting Students Responsible Environmental Behavior (REB) Based on Personality Stidents New Environmental Paradigm (NEP) and Naturalistic Intelligence. The Journal of Advanced Science Letters. 23(9), 8586-8593.

Ritzer, C. J. (1975). Sociology A Multiple Paradigm Science. New York: Allyn and Bacon.

Thomson, J., (2013). New Ecological Paradigm Survey 2008: Analysis of NEP results. Waikato Regional Council: Technical Report.

Valentin, J. and Gamez, L. (2010). Environmental Psychology New Development. New York: Nova Science Publisher.

Wardhani, R. R. N. (2017). Pengaruh Personality dan New Environmental Paradigm (NEP) terhadap Responsible Environmental Behaviour (REB) Siswa. Skripsi, UNJ. 